Article

\title{
Human Antimicrobial Peptide Hepcidin 25-Induced Apoptosis in Candida albicans
}

\author{
Ruei-Ching Chen ${ }^{1}$ and Chung-Yu Lan ${ }^{2, *}$ (B) \\ 1 Institute of Molecular and Cellular Biology, National Tsing Hua University, Hsinchu 30013, Taiwan; \\ a104080818@gapp.nthu.edu.tw \\ 2 Department of Life Science, National Tsing Hua University, Hsinchu 30013, Taiwan \\ * Correspondence: cylan@life.nthu.edu.tw; Tel.: +886-3-574-2473
}

Received: 2 March 2020; Accepted: 15 April 2020; Published: 17 April 2020

\begin{abstract}
Hepcidin 25 (hep 25) is a cysteine-rich 25-amino acid antimicrobial peptide containing the amino-terminal $\mathrm{Cu}(\mathrm{II}) / \mathrm{Ni}(\mathrm{II})$-binding (ATCUN) motif. Upon metal binding, the ATCUN motif is known to be involved in the generation of reactive oxygen species (ROS), especially hydrogen peroxide and hydroxyl radicals, which act against different bacterial species. However, the antifungal activity and its correlation to the $\mathrm{Cu}$ (II)-ATCUN complex of Hep 25 are still poorly understood. Here, we found that ROS accumulation plays an important role in the fungicidal activity of hep 25 against Candida albicans. In addition, Annexin V-FITC staining and TUNEL assay results provide clues about the apoptosis induced by hep 25. Moreover, hep 25 also increases the generation of ROS, possibly because of copper binding to the ATCUN motif, which is relevant to its activity against C. albicans. Finally, the C. albicans killing action of hep 25 is an energy- and temperature-dependent process that does not involve targeting the membrane. Taken together, our results provide new insights into the mechanisms of hep 25 against C. albicans cells and the potential use of hep 25 and its derivatives as novel antifungal agents.
\end{abstract}

Keywords: C. albicans; antimicrobial peptide; hepcidin-25; apoptosis

\section{Introduction}

The Candida albicans fungus is not only a member of the normal microbiota of healthy individuals, but also an opportunistic human pathogen [1,2]. Under normal conditions, C. albicans commensally colonizes the skin and mucosal surfaces without causing harm. However, it can become pathogenic and cause various clinical manifestations, including life-threatening systemic infection with a high mortality rate, particularly in immunocompromised patients [3,4]. Moreover, the antifungal drug resistance of $C$. albicans is also an expanding problem in clinical settings. Nowadays, only few classes of antifungals are currently available to treat $C$. albicans infections. Therefore, it is urgently required to develop new effective antifungal drugs.

Antimicrobial peptides (AMPs) play crucial roles in human innate immunity to combat microbial infections [5,6]. Additionally, human AMPs also contribute to diverse biological processes such as cell proliferation, wound healing and immune modulation [7,8]. Most AMPs comprise fewer than 100 amino acid residues and are positively charged and amphipathic [9]. AMPs are produced not only in humans but also in a wide variety of organisms, including bacteria, insects and plants [10]. To date, more than 3000 AMPs have been identified and cataloged in the antimicrobial peptide database (http://aps.unmc.edu/AP/), and the numbers of newly identified AMPs is increasing [11,12]. Because of a broad spectrum of targeted microorganisms, multiple mechanisms of action and relatively resistant variants, AMPs have the potential for therapeutic application. Several human AMPs are currently 
being tested in clinical trials, including LL37, PAC-113 (a derivative of salivary histatin 3) and PXL01 (a derivative of lactoferricin) $[11,13,14]$.

Hepcidin 25 (hep 25) is a 25 -amino acid $\beta$-defensin-like peptide that was first discovered in human urine and blood ultrafiltrate and found to be synthesized in the liver [15]. Hep 25 contains eight cysteine residues that form four disulfide bridges important for maintaining correct peptide folding and stabilizing the $\beta$-hairpin structure. Hep 25 is highly conserved in vertebrate species, particularly the eight cysteine residues and the N-terminal region containing the ATCUN motif [16,17]. Importantly, the ATCUN motif (H2N-X-X-H, where $\mathrm{X}$ is variable) is capable of specifically binding $\mathrm{Cu}(\mathrm{II})$ and $\mathrm{Ni}(\mathrm{II})$ metals. Moreover, the N-terminus of hep 25 is also critical for the interaction with the sole iron transporter, ferroportin (Fpn), to trigger internalization and degradation of Fpn, thereby acquiring nutritional immunity that limits pathogenicity during infection [18-20]. In addition to a master of iron regulation in the human body, Hep 25 is also an AMP with broad antimicrobial activity against gram-positive bacteria (e.g., Staphylococcus aureus, Staphylococcus epidermidis, Enterococcus faecium), gram-negative bacteria (e.g., Pseudomonas aeruginosa, Escherichia coli, Acinetobacter baumannii) and fungi (e.g., C. albicans and Saccharomyces cerevisiate) without causing cytotoxicity in mammalian cells [15,21-24]. Importantly, the bactericidal activity of hep 25 is dependent on the integrity of the disulfide bridges and correct folding of hep 25 [25]. Copper(II) chloride $\left(\mathrm{CuCl}_{2}\right)$ can slightly enhance the bactericidal activity associated with the ATCUN motif [22]. Enhancing the bactericidal activity of hep 25 in acidic conditions has also been reported because the protonation states of its histidine residues increase the net positive charge of the peptide [22,26]. Although many studies have focused on the action of hep 25 against bacteria, the killing mechanism of hep 25 against fungal pathogens remains unknown.

In this study, we investigated the mechanism of hep 25 against $C$. albicans and showed that hep 25-mediated C. albicans killing is an energy- and temperature-dependent process without membrane lysis, making it similar to the mechanism of cell-penetrating peptides (CPPs). Moreover, the generation of reactive oxygen species (ROS) is coincident with the candidacidal activity of hep 25, and the copper-ATCUN complex of hep 25 is possibly the major driver of ROS production. Finally, hep 25 induced cell apoptosis of $C$. albicans cells. To our knowledge, this is the first report showing that hep 25 can cause apoptosis of a fungal pathogen cells and cross the membrane in a nonlytic manner.

\section{Materials and Methods}

\subsection{Peptides and Regents}

Hep 25 (H-Asp-Thr-His-Phe-Pro-Ile-Cys-Ile-Phe-Cys-Cys-Gly Cys-Cys-His-Arg-Ser-Lys-CysGly Met-Cys-Cys-Lys-Thr-OH trifluoroacetate salt) was purchased from Bachem AG (Bubendorf, Switzerland). High-performance chromatography (HPLC) analysis showed that purity of the peptide was $>90 \%$. A stock solution of hep 25 was prepared in sterile double distilled water $\left(\mathrm{ddH}_{2} \mathrm{O}\right)$ and stored at $-20{ }^{\circ} \mathrm{C}$. All reagents were obtained from Sigma-Aldrich (St. Louis, MO, USA) unless indicated otherwise.

\subsection{C. albicans Strain and Growth Conditions}

The C. albicans SC5314 strain [27] was used throughout this study. Cells were plated on YPD agar ( $1 \%$ yeast extract, $2 \%$ Bacto peptone, $2 \%$ glucose and $1.5 \%$ agar) and grown overnight at $30{ }^{\circ} \mathrm{C}$ before each experiment. One colony was inoculated into $5 \mathrm{~mL}$ of YPD broth and incubated overnight $(\sim 14$ to $16 \mathrm{~h}$ ) at $30^{\circ} \mathrm{C}$ with sharking at $180 \mathrm{rpm}$. Cells were harvested by centrifugation, washed twice with sterile sodium phosphate buffer $(\mathrm{SPB})$, subcultured in YPD medium (OD600 $=0.2)$, and continuously grown to the exponential phase. 


\subsection{Calcein Leakage Assay}

The effect of hep 25 on the integrity of the C. albicans plasma membrane was determined by measuring the leakage of calcein from small unilamellar liposome vesicles (SUVs, $100 \mathrm{~nm}$ diameter). The SUVs were composed of phosphatidylcholine (PC), phosphatidylethanolamine (PE), phosphatidylinositol (PI) and ergosterol in a ratio of 5:4:1:2 (w/w/w/w) and were prepared as previously described [28] with some modifications. The SUVs were treated with various concentrations $(0,6.25$, $12.5,25$ and $50 \mu \mathrm{g} / \mathrm{mL}$ ) of hep 25 at room temperature (RT). To evaluate pore formation and membrane integrity, a Cary Eclipse Fluorescence Spectrophotometer (PerkinElmer, Santa Clara, CA, USA) was used to measure the leakage of the calcein dye at excitation ( $\lambda$ ex) and emission ( $\lambda \mathrm{em}$ ) of $490 \mathrm{and} 535 \mathrm{~nm}$, respectively. The percentage of dye-leakage was calculated as follows: \% dye leakage $=100 \times[(\mathrm{F}-$ $\mathrm{F} 0) /(\mathrm{Ft}-\mathrm{F} 0)]$, where $\mathrm{F}$ is the fluorescence intensity after the peptide treatment, $\mathrm{Ft}$ is the fluorescence intensity with Triton X-100, and F0 is the fluorescence intensity of the untreated control SUVs. PC, PE and PI were purchased from Avanti Polar Lipids (Alabaster, AL, USA).

\subsection{C. albicans Killing Assay}

The antifungal susceptibility assay was performed as previously by colony-forming-unit (CFU) counting and propidium iodide (PI) staining as previously described [29] with some modifications. After growing overnight, C. albicans cells were subcultured in YPD, and grown at $30^{\circ} \mathrm{C}$ for another $4.5 \mathrm{~h}$. After collection by centrifugation, cell pellets were washed twice with $10 \mathrm{mM}$ sterile sodium phosphate buffer (SPB, pH 5.8) and resuspended in SPB to $2.4 \times 10^{7}$ cells $/ \mathrm{mL}$. Different concentrations of hep 25 were added to the cells, which were then incubated at $37^{\circ} \mathrm{C}$ for $90 \mathrm{~min}$. Each sample was serially diluted 10-fold, plated on YPD agar and incubated overnight at $30^{\circ} \mathrm{C}$. Cell viability was assessed by the number of CFUs. For PI staining, cells were treated with or without different concentrations of hep 25 as described above and harvested by centrifugation. After washing twice with phosphate-buffered saline (PBS), cells were resuspended in PBS containing $5 \mu \mathrm{g} / \mathrm{mL}$ PI. A flow cytometer (BD Accuri ${ }^{\circledR}$ C6, BD Biosciences, San Jose, CA, USA) with the FL2 filter was used to measure the fluorescence intensity of PI-positive cells. Data analysis was performed using the BD Accuri ${ }^{\circledR}$ C6 software (Version 1.0.26421) and discrimination of living cells and cell debris was based on forward versus side scatter (FSC vs. SSC). For each assay, 10,000 cells were analyzed, and the percentage of the PI-positive cells was displayed. Cells without hep 25 treatment were used as negative controls. All the experiments were repeated at least three times and the average fluorescence intensity was determined.

\subsection{Analysis of Apoptotic Markers}

Annexin V-FITC and propidium iodide (PI) staining was performed as previously described [30] with some modifications. Briefly, C. albicans cells were treated with various concentrations of hep 25 at $37^{\circ} \mathrm{C}$ for $90 \mathrm{~min}$. The cells were harvested by centrifugation, washed twice with phosphate-buffered saline (PBS), resuspended in 0.1 M potassium phosphate buffer (PPB, pH 7.2) containing $0.02 \mathrm{mg} / \mathrm{mL}$ Zymolyase 20T (Seikagaku, Inc., Tokyo, Japan) and sorbitol (at a final concentration of $2.4 \mathrm{M}$ ) at $30{ }^{\circ} \mathrm{C}$ for $10 \mathrm{~min}$ [31]. To asses externalization of phosphatidylserine (PS), the resulting protoplasts were stained with PI and FITC-labeled Annexin-V using the Annexin V-FITC/PI Apoptosis Detection Kit (Elabscience, Catalog \#E-CK-A211, Huston, TX, USA) according to the manufacturer's instruction. The stained cells were analyzed using a flow cytometer (BD Accuri ${ }^{\circledR}$ C6, BD Biosciences). For each assay, 20,000 cells were analyzed and the percentage of the Annexin V-FITC positive and PI positive/negative cells in total cell population was displayed.

Terminal deoxynucleotidyl transferase dUTP nick-end labeling (TUNEL) (Roche, Catalog \# 11684795910, Indianapolis, IN, USA) was performed as previously described [32] with some modifications. C. albicans cells were treated with various concentrations of hep 25 at $37{ }^{\circ} \mathrm{C}$ for $90 \mathrm{~min}$. The cells were harvested by centrifugation, washed twice with PBS and fixed with $4 \%$ PFA at $30{ }^{\circ} \mathrm{C}$ for $15 \mathrm{~min}$. The samples were then washed twice with PBS and incubated with $0.1 \mathrm{M}$ PPB 
( $\mathrm{pH} 7.2$ ) containing $0.02 \mathrm{mg} / \mathrm{mL}$ Zymolyase $20 \mathrm{~T}$ and sorbitol (at a final concentration of $2.4 \mathrm{M}$ ) at $30{ }^{\circ} \mathrm{C}$ for $10 \mathrm{~min}$. After washing twice with PBS, permeabilization solution (0.1 M sodium citrate [pH 6.0], with $0.1 \%$ Triton $\mathrm{X}-100$ ) was added to the sample, incubated on ice for $2 \mathrm{~min}$ and washed again with PBS. Thereafter, fluorescein from an in situ cell death detection kit was used according to the manufacturer's instructions (Roche Diagnostics GmbH, Mannheim, Germany), and the cells were examined using a confocal microscope (ZEISS LSM 800, Carl Zeiss, Jena, Germany).

\subsection{Cytosolic ROS Assay}

To detect intracellular ROS accumulation and hydroxyl radical production, dihydroethidium (DHE) and hydroxyphenyl fluorescein (HPF) (Cayman Chemical) fluorescent dyes were used, respectively [28,31]. C. albicans cells were treated with various concentrations of hep 25, $10 \mathrm{mM}$ hydrogen peroxide $\left(\mathrm{H}_{2} \mathrm{O}_{2}\right)$ and $1 \mathrm{mM}$ bathocuproinedisulfonic acid (BCS) at $37^{\circ} \mathrm{C}$ for $90 \mathrm{~min}$. The cells were harvested, washed twice with PBS and stained with $20 \mu \mathrm{g} / \mathrm{mL}$ DHE or $5 \mu \mathrm{M}$ HPF. The cells were then analyzed using a flow cytometer (BD Accuri ${ }^{\circledR}$ C6, BD Biosciences) withthe FL1 filter (for HFP) and FL2 filter (for DHE), respectively.

\subsection{Detection of Mitochondrial Membrane Potential ( $\Delta \Psi m$ )}

Mitochondrial function was assessed using 3,3'-dihexyloxacarbocyanine iodide (DiOC6(3); Molecular Probes) and tetramethylrhodamine (TMRM; Thermo Fisher), which are cell-permeant fluorescent dyes taken up by mitochondria in a $\Delta \Psi \mathrm{m}$-dependent manner $[33,34]$. In healthy cells with a high $\Delta \Psi \mathrm{m}$, both of these mitochondrial membrane-sensitive dyes aggregated in the mitochondrial matrix and showed a high fluorescence signal compared to the distribution and signal observed in the cells in which damage had eliminated the $\Delta \Psi \mathrm{m}$. C. albicans cells were treated with various concentrations of hep 25 at $37^{\circ} \mathrm{C}$ for $90 \mathrm{~min}$. The cells were then washed twice with PBS and stained with $50 \mathrm{nM}$ DiOC6(3) or $100 \mathrm{nM}$ TMRM at $37^{\circ} \mathrm{C}$ for $30 \mathrm{~min}$. The fluoresce intensity was analyzed using a flow cytometer (BD Accuri ${ }^{\circledR}$ C6, BD Biosciences) with the FL2 filter.

\subsection{Metacaspase Activity Assay}

The activation of metacaspase was detected as previously described [35]. C. albicans cells were treated with various concentrations of hep 25 at $37^{\circ} \mathrm{C}$ for $90 \mathrm{~min}$, collected by centrifugation, and washed with PBS. The cells were then stained with $10 \mu \mathrm{M}$ CaspACE ${ }^{\mathrm{TM}}$ FITC-VAD-FMK in situ marker (Promega, Catalog \#G746A, Madison, WI, USA) at RT for $30 \mathrm{~min}$ in the dark. Thereafter, the cells were harvested, washed twice, resuspended in PBS and analyzed using a flow cytometer (BD Accuri ${ }^{\circledR}$ C6, BD Biosciences) with the FL1 filter.

\subsection{Statistical Analysis}

The data were assessed for statistical significance by two-tailed Student's $t$-tests. Statistical significance was indicated with a $p$-value $<0.05$.

\section{Results}

3.1. Hep 25 Shows Potent Candidacidal Activity in an Energy-and Temperature-Dependent Manner Without Causing Membrane Disruption

In this study, the activity of hep 25 (Table 1) was characterized. 
Table 1. Amino acid sequence and physicochemical properties of Hep25.

\begin{tabular}{cccccc}
\hline \multirow{2}{*}{ Peptide } & Amino Acid Sequence & $\begin{array}{c}\text { Disulfide } \\
\text { Bonds }\end{array}$ & $\begin{array}{c}\text { Molecular } \\
\text { Mass (Da) }\end{array}$ & $\begin{array}{c}\text { Net } \\
\text { Charge a }\end{array}$ & $\begin{array}{c}\text { Hydrophobicity } \\
\text { a }\end{array}$ \\
\hline \multirow{2}{*}{ Hep 25 } & DTHFPICIFCCGCCHRSKCGMCCKT & $\begin{array}{c}7-23,10-13, \\
11-19,14-22\end{array}$ & 2789.4 & 2 & $52 \%$ \\
\hline
\end{tabular}

${ }^{a}$ Net charge and Hydrophobic ratio were calculated using the Antimicrobial Peptide Calculator and Predictor (http://aps.unmc.edu/AP/prediction/prediction_main.php).

To determine the efficiency of hep 25 against $C$. albicans, cell susceptibility assays were performed. As shown in Figure 1A, the viability of $C$. albicans cells after hep 25 treatment decreased with increasing concentrations of hep 25. Moreover, cell viability upon hep 25 treatment was also assessed using PI staining. Figure 1B shows that the number of inviable PI-positive cells increased with increasing concentrations of hep 25. To further verify the efficacy of hep 25, the susceptibilities of various clinical isolates of C. albicans and non-albicans Candida species (Table S1) to the peptide were also tested. Table S2 shows that the overall minimal fungicidal concentrations (MFCs) of hep 25 against non-albicans Candida spp. were lower than that of $C$. albicans isolates. Similarly, a sublethal dose $(12.5 \mu \mathrm{g} / \mathrm{mL})$ of hep 25 against the $C$. albicans isolates had a greater impact on cell survival of non-albicans Candida spp. (Figure S1). The results showed that hep 25 is not only effective against $C$. albicans but also non-albicans Candida spp.

(A)

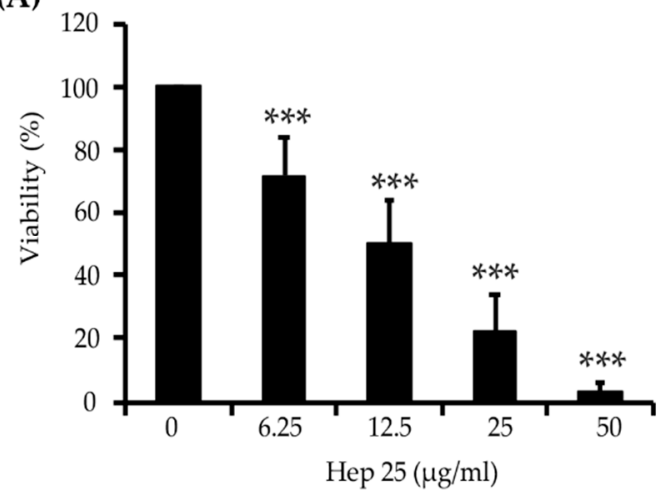

(B)

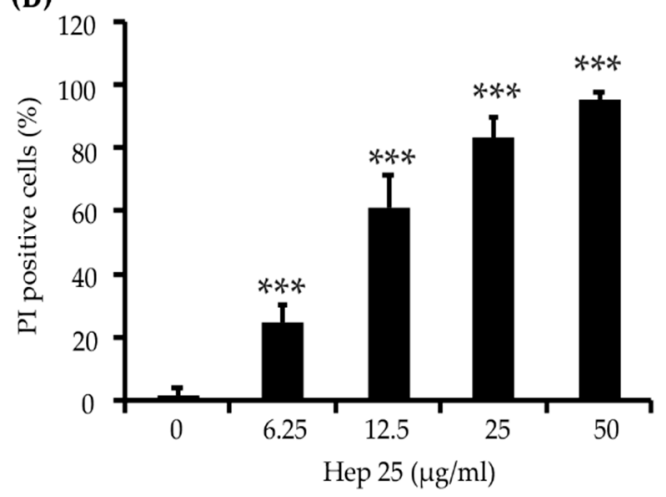

Figure 1. C. albicans killing assay of hep 25. (A) Killing of C. albicans by hep 25 was determined by the number of CFUs and expressed as the percentage of viable cells; ${ }^{* * *} p<0.001$. (B) The killing activity of hep 25 was detected by PI staining. The cells killed by hep 25 (PI-positive cells) were quantified by flow cytometry and reported as a percentage. The results are presented as the mean \pm standard deviation of three independent experiments; ${ }^{* * *} p<0.001$.

The functions of AMP are generally either membrane targeting or nonmembrane targeting [7]. Because hep 25 causes $C$. albicans cell death, we were interested in determining whether hep 25 has membrane-disruption ability. Here, we detected the calcein leakage from SUVs that mimic the plasma membrane of C. albicans cells [28]. The calcein leaked from SUVs treated with $0.1 \%$ Triton X-100 treatment was used as a positive control and defined as having $100 \%$ leakage. Interestingly, no or negligible signals were detected in the SUVs treated with different concentrations of hep 25 after incubation for $1 \mathrm{~min}$ (Figure 2A) and $90 \mathrm{~min}$ (Figure 2B). These results suggest that hep 25-mediated C. albicans killing is independent of disrupting the membrane integrity. 

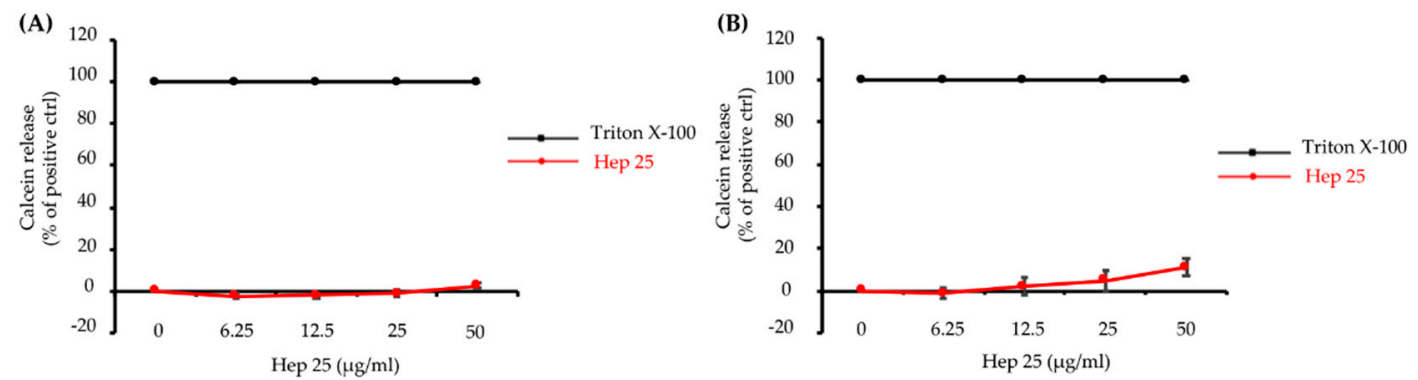

Figure 2. The effect of hep 25 on membrane integrity. Leakage of calcein from SUVs [PC:PE:PI:ergosterol $=5: 4: 1: 2(w / w / w / w)]$ was monitored after treatment with hep 25 for (A) $1 \mathrm{~min}$ and (B) $90 \mathrm{~min}$. The induced calcein leakage was expressed as a percentage. Calcein leakage from the SUVs treated with $0.1 \%$ Triton $\mathrm{X}-100$ was used as a positive control and defined as 100\% leakage. The results are expressed as the mean \pm standard deviation of three independent experiments.

It is known that some AMPs can enter cells without damaging the plasma membrane in an energy-dependent manner. For example, histatin 5 (Hst 5) gains access to the cytosol through transporters or receptor-mediated endocytosis [36-38], whereas pep-1 translocates through a physical-mediated mechanism [39]. To determine whether hep 25 translocation across the membrane requires energy consumption, cells were pretreated with the metabolic inhibitors sodium azide $\left(\mathrm{NaN}_{3}\right)$ and carbonyl cyanide m-chlorophenyl hydrazine (CCCP) and then incubated with hep 25. $\mathrm{NaN}_{3}$ inhibited the mitochondrial complex IV, blocking mitochondrial respiration, whereas CCCP destroyed the proton gradient generated in mitochondria, blocking ATP synthesis [40]. The results indicated that both $\mathrm{NaN}_{3}$ and CCCP can rescue cells from hep 25 killing, as determined by the number of CFUs (Figure 3A) and PI staining evidence (Figure 3B). Low temperatures diminish cell metabolism and ATP synthesis, and moreover, they can be used to determine the entry of AMPs into cells by distinguishing translocation (occurs at $37^{\circ} \mathrm{C}$ and $4{ }^{\circ} \mathrm{C}$ ) from endocytosis (occurs only at $37^{\circ} \mathrm{C}$ ) [40-43]. Therefore, to further determine the method by which hep 25 gains access to $C$. albicans, cells were incubated with hep 25 at $4{ }^{\circ} \mathrm{C}$ and $37^{\circ} \mathrm{C}$, and cell viability was measured. The candidacidal activity of hep 25 was reduced at $4{ }^{\circ} \mathrm{C}$ compared to that at $37^{\circ} \mathrm{C}$, as demonstrated by the number of CFUs (Figure 3C) and the PI staining evidence (Figure 3D). Taken together, these findings suggest that endocytosis may be the process by which hep 25 is transported into C. albicans cells. 

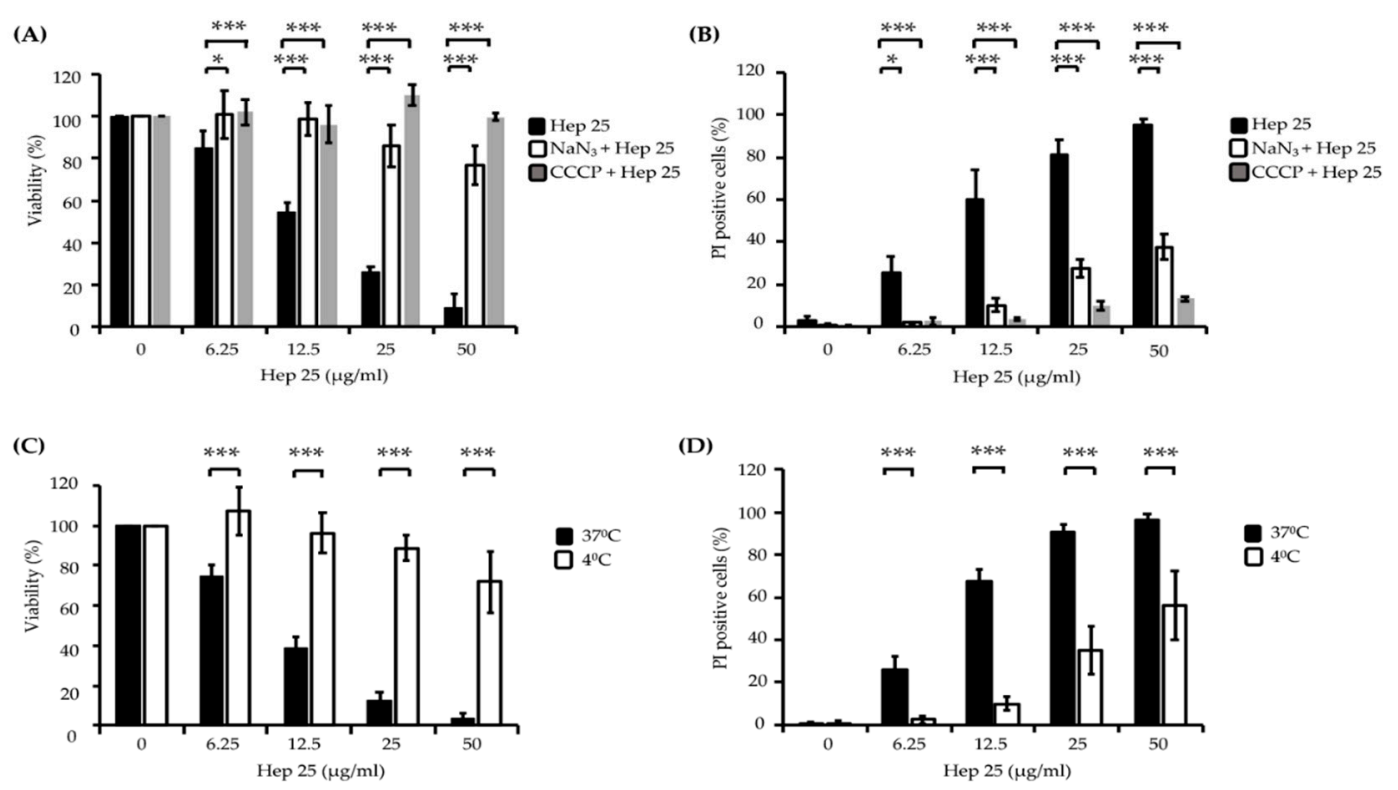

Figure 3. The effect of energy and temperature on the killing activity of hep 25. C. albicans cells were pretreated with $5 \mathrm{mM} \mathrm{NaN}_{3}$ for $1 \mathrm{~h}$ or $50 \mu \mathrm{M} \mathrm{CCCP}$ for $2 \mathrm{~h}$ at $30^{\circ} \mathrm{C}$ to deplete cellular ATP, harvested by centrifugation, washed with sterile PBS and incubated with various concentrations of hep 25 at $37^{\circ} \mathrm{C}$ for $90 \mathrm{~min}$. (A) Cell viability was calculated by the number of CFUs and expressed as percentage with respect to the control cells (without hep 25 treatment). (B) Cells stained with PI were detected using a flow cytometer and expressed as percentages. C. albicans cells were treated with various concentrations of hep 25 at $4{ }^{\circ} \mathrm{C}$ for $90 \mathrm{~min}$. (C) Candidacidal activity of hep 25 was determined by the number of CFUs and expressed as the percentage of viable cells. (D) The extent of hep 25 -induced death as detected by PI staining. All the results are expressed as the mean \pm standard deviation of three independent experiments; ${ }^{*} p<0.05$ and ${ }^{* * *} p<0.001$.

\subsection{The ATUCN Motif of Hep 25 Is Involved in ROS Production and Correlates with the Activity of Hep 25}

ROS play roles in the apoptosis of different cell types, and the induction of ROS production is also an important antimicrobial mechanism for many AMPs [44,45]. Several studies show that the ATCUN motif is related to the ability of certain AMPs to promote the production of ROS, particularly hydrogen peroxide and hydroxy radicals involving redox-active metals and a Fenton-like reaction [46-50]. DHE and HPF staining were used to detect hydrogen peroxide and hydroxyl radical levels, respectively. The fluorescence intensity of these ROS indicators was proportional to the ROS levels determined by the flow cytometry analysis [51,52]. As shown in Figure 4A,B, the fluorescence intensity of DHE and HPF was enhanced in the $C$. albicans cells treated with various concentrations of hep 25. 
(A)

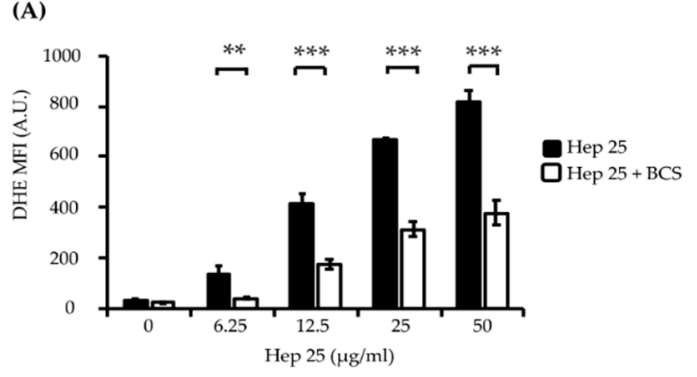

(B)

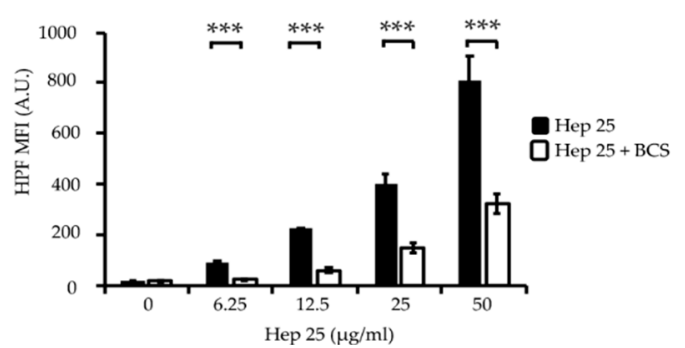

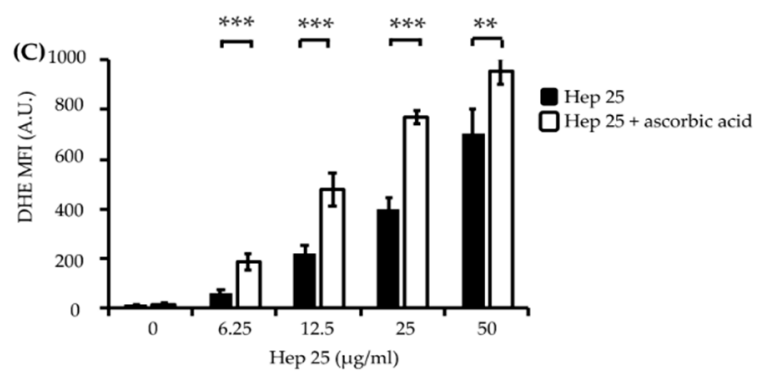

Figure 4. The induction of intracellular ROS production by hep 25. Intracellular ROS production was assessed through DHE $(\mathbf{A}, \mathbf{C})$ and $\operatorname{HPF}(\mathbf{B})$ staining and flow cytometry. The black bar and white bar show cells treated with hep 25 and cotreated with $1 \mathrm{mM}$ BCS or $10 \mathrm{mM}$ ascorbic acid and hep 25, respectively. MFI, mean fluorescence intensity and A.U., arbitrary unit. The results are presented as the mean \pm standard deviation of three independent experiments; ${ }^{* *} p<0.01$ and ${ }^{* * *} p<0.001$.

Bathocuproinedisulfonic acid (BCS) is a chelator known to block copper binding to the ATCUN motif-containing AMP histatin-5, leading to abrogated fungicidal activity of the peptide [50]. Interestingly, the fluorescence intensity of DHE and HPF in the cells cotreated with $1 \mathrm{mM}$ BCS and hep 25 was significantly reduced (Figure 4A,B). Ascorbic acid (vitamin C) has been shown to act as a metal reducing agent to enhance the copper redox cycling of the $\mathrm{Cu}$ (II)-ATCUN motif, which is involved in ROS production through a Fenton-like reaction [53-55]. Therefore, to further verify the ROS production, cells were cotreated with ascorbic acid and hep 25 . The results show that cells cotreated with hep 25 and ascorbic acid have a higher level of ROS production than that treated with hep 25 alone (Figure 4C). Moreover, the candidacidal activity of hep 25 was also reduced in the presence of $\mathrm{BCS}$, as revealed by the number of CFUs and PI staining evidence (Figure 5A,B).
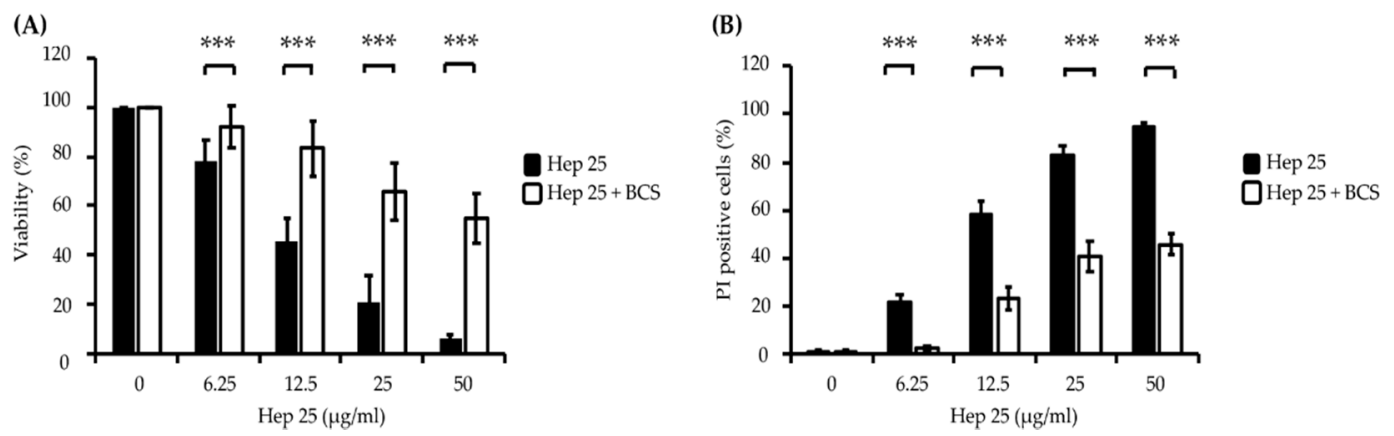

Figure 5. The effect of BCS on the candidacidal activity of hep 25. (A) Killing of C. albicans cells by hep 25 cotreated with or without $1 \mathrm{mM} \mathrm{BCS}$ was determined by the number of CFUs and expressed as the percentage of viable cells; ${ }^{* * *} p<0.001$. (B) The killing activity of hep 25 with or without $1 \mathrm{mM} \mathrm{BCS}$ was detected by PI staining. The cells killed by hep 25 with or without $1 \mathrm{mM}$ BCS were quantified by flow cytometry and reported as a percentage. The results are presented as the mean \pm standard deviation of three independent experiments; ${ }^{* * *} p<0.001$. 


\subsection{Hep 25 Induces Mitochondrial Depolarization in C. albicans}

Excessive ROS production causes oxidative stress, damages vital components of cells and induces cell death $[56,57]$. Because hep 25 does not seem to cause membrane disruption in $C$. albicans cells (Figure 2A,B), we were interested in the mechanism by which hep 25 causes cell death. Therefore, several hallmarks of apoptosis including mitochondrial depolarization, phosphatidylserine exposure and DNA fragmentation [58] were measured. To determine possible mitochondrial depolarization induced by hep 25, the lipophilic cell-permeant green-fluorescent dye DiOC6(3) was used. DiOC6(3) selectively detects the mitochondrial membrane potential $(\Delta \Psi \mathrm{m})$ of live cells [59]. Loss of $\Delta \Psi \mathrm{m}$ is common during early apoptosis; therefore, mitochondrial depolarization is an indicator of mitochondrial-mediated apoptosis [60,61]. In this study, cells treated with the carbonyl cyanide m-chlorophenyl hydrazine (CCCP) and cells without treatment were used as the positive and negative controls, respectively. As shown in the flow cytometric analysis (Figure S2 and Figure $6 \mathrm{~A}$ ), the $\Delta \Psi \mathrm{m}$ of the CCCP-treated cells was reduced compared to that of the negative control cells. Similar results were also found in cells treated with different concentrations of hep 25 (Figure S2 and Figure 6A). To verify this finding, another cell-permeant, the cationic fluorescent dye tetramethylrhodamine methyl ester (TMRM) was also used. TMRM accumulates in the highly negatively charged interior of mitochondria and its fluorescence intensity reflects the $\Delta \Psi \mathrm{m}$ across the inner mitochondrial membrane [59]. A loss of $\Delta \Psi \mathrm{m}$ results in the TMRM leakage from the mitochondria. As shown in Figure S3 and Figure 6B, the fluorescence intensity decreased in cells treated with hep 25 , suggesting that hep 25 causes mitochondrial depolarization.

(A)

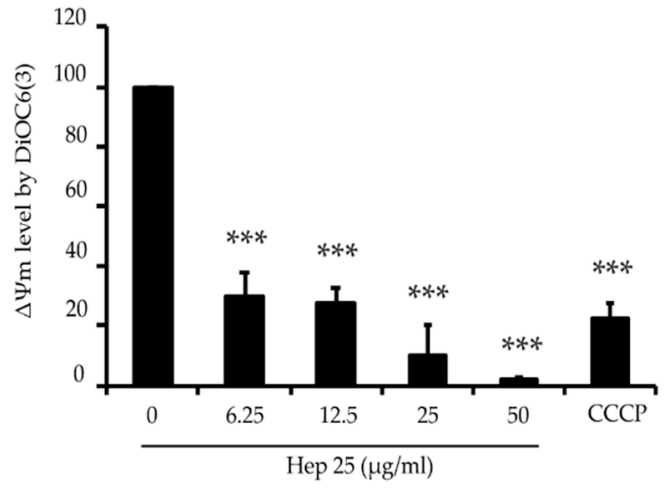

(B)

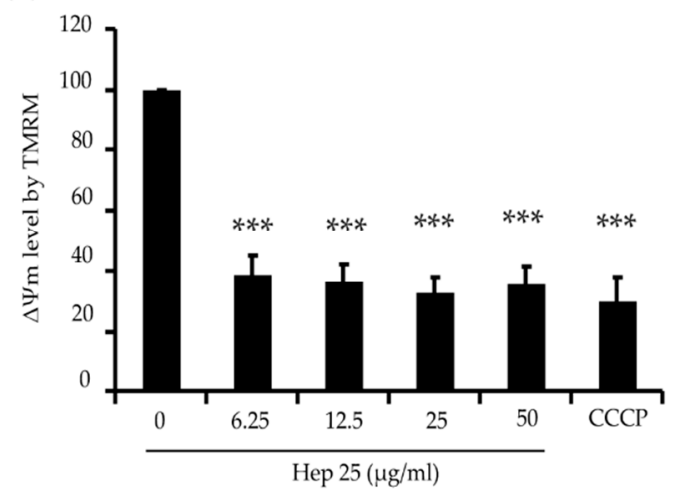

Figure 6. Mitochondrial depolarization caused by hep 25. Depolarization of the mitochondrial membrane was detected by DiOC6(3) (A) and TMRM (B) staining and analyzed using flow cytometry and quantification data. $\mathrm{CCCP}(50 \mu \mathrm{M})$ was used as a positive control for disruption of the mitochondrial membrane potential $(\Delta \Psi \mathrm{m})$. The results are expressed as the mean \pm standard deviation of three independent experiments; ${ }^{* * *} p<0.001$.

\subsection{Hep 25 Triggers Metacaspase Activation}

Metacaspases are found in protozoa, fungi and plants, where they play important roles in regulating apoptosis [62]. Moreover, ROS accumulation and mitochondrial dysfunction are associated with metacaspase activation $[63,64]$. To verify that hep 25 is an apoptotic stimulus, metacaspase activity was measured using a CaspACETM FITC-VAD-FMK in situ marker [65]. As shown in Figure 7A,B, an increase in FITC fluorescence intensity was detected with increasing concentrations of hep 25, indicating that hep 25 triggers metacaspase activation. 
(A)

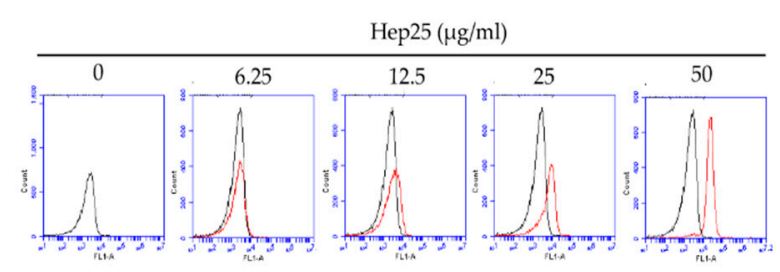

(B)

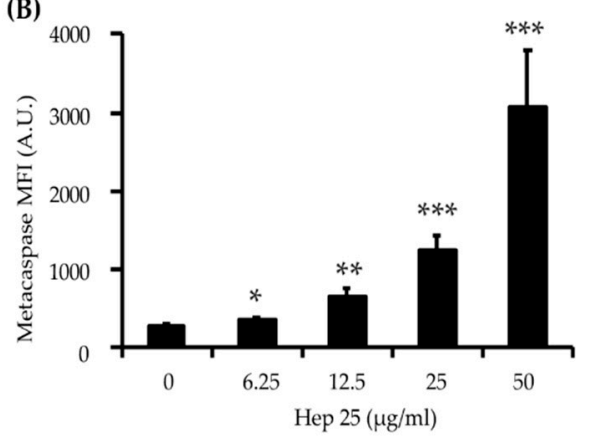

Figure 7. The activation of metacaspases by hep 25. Metacaspase activity induced by hep 25 was detected using the FITC-VAD-FMK in situ marker. In the flow cytometry data (A), the black line represents the cells without hep 25 treatment, which served as the negative control. The red line represents cells treated with various concentrations of hep 25. After treatment with hep 25, the cells were incubated with FITC-VAD-FMK for $20 \mathrm{~min}$ at RT in the dark and analyzed with a flow cytometer. The quantification data for $(\mathbf{B})$. The results are expressed as the mean \pm standard deviation of three independent experiments; ${ }^{*} p<0.05 ;{ }^{* *} p<0.01$; and ${ }^{* * *} p<0.001$.

\subsection{Phosphatidylserine was Externally Exposed in C. albicans Treated with Hep 25}

To further reveal the action of hep 25, cell death caused by hep 25 was also evaluated using Annexin V-FITC and PI staining. FITC-conjugated Annexin V specifically binds to PS, which is translocated to the outer leaflet of the plasma membrane during early apoptosis, staining the cell surface green. Moreover, after PS translocation, cells lose their plasma membrane integrity, allowing the red fluorescent PI dye to pass through and bind to nucleic acids. Therefore, cells stained with Annexin V-FITC are apoptotic [58,66]. Our results showed that the number of Annexin V-FITC positive cells increase after treatment with difference concentration of hep 25 compared to the control cells (without hep 25 treatment) (Figure 8A-F). These results suggest that hep 25 induces $C$. albicans apoptosis.
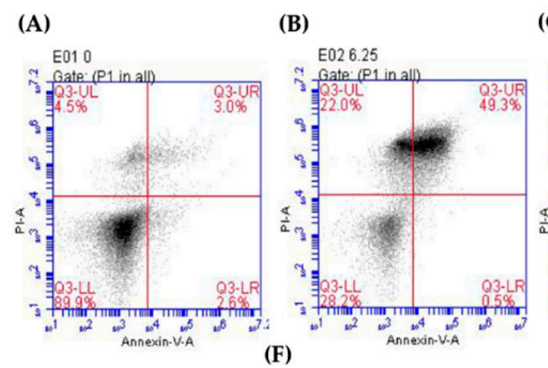

(C)
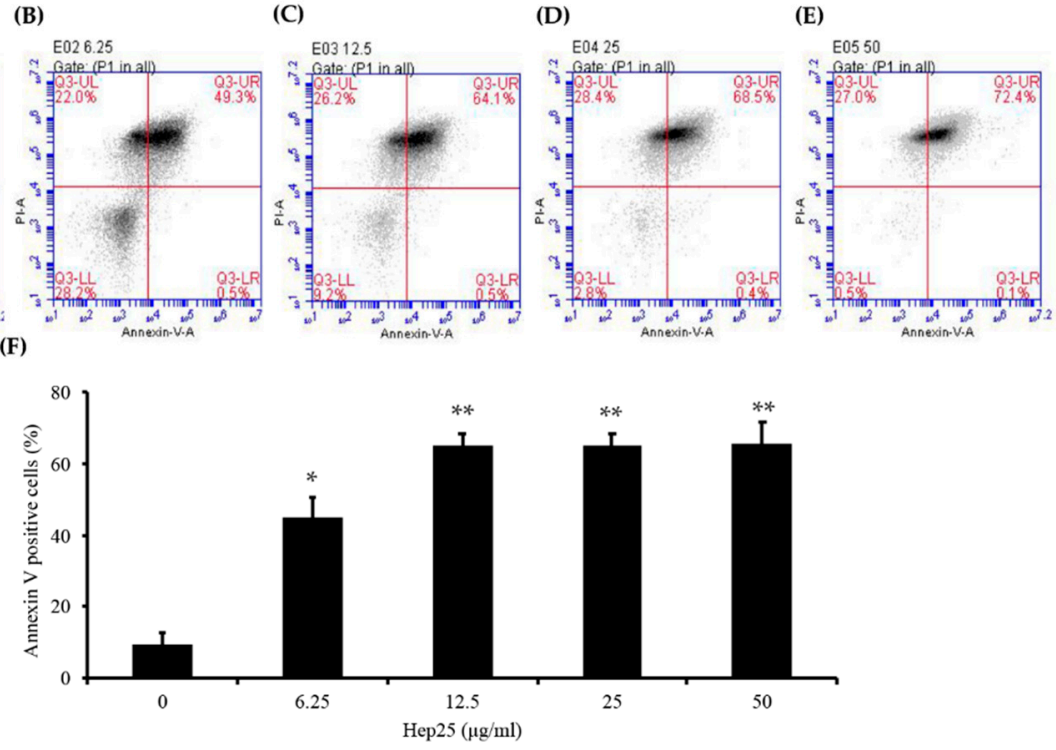

Figure 8. The induction of phosphatidylserine exposure by hep 25. After treatment with various concentrations of hep 25-(A) 0, (B) $6.25 \mu \mathrm{g} / \mathrm{mL}$, (C) $12.5 \mu \mathrm{g} / \mathrm{mL}$,(D) $25 \mu \mathrm{g} / \mathrm{mL}$, and (E) $50 \mu \mathrm{g} / \mathrm{mL}$ - protoplasts were stained with Annexin V-FITC and PI and analyzed by flow cytometry. (F) The early and late apoptotic cells were stained with Annexin V-FITC (as shown in lower right quadrant, LR and higher right quadrant, UR). The percentage of apoptotic cells in total cell population was calculated. The data represent the mean \pm standard deviation for three independent experiments; ${ }^{*} p<0.05 ;{ }^{* *} p<0.01$. 
Finally, a FITC-dUTP nick-end labeling (TUNEL) assay $[35,67,68]$ was also performed to detect DNA fragmentation in cells treated with hep 25. Figure 9 shows that there was no signal in the control cells; however green fluorescence was observed in the cells treated with hep 25. In summary, these results suggest that hep 25 induces $C$. albicans cells apoptosis.

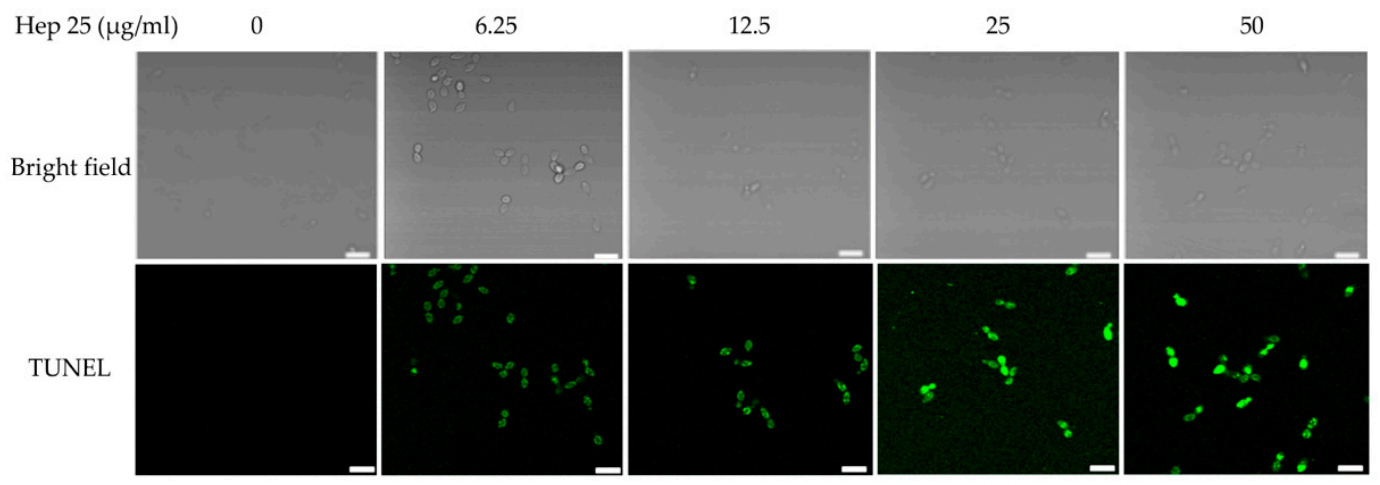

Figure 9. DNA fragmentation caused by hep 25. Cells were treated with various concentrations of hep 25 , and the DNA damage was determined using the TUNEL assay. Images were taken using a laser scanning confocal microscope with a $60 \times$ oil objective lens. Bar, $10 \mu \mathrm{m}$. The representative images from three independent experiments with similar results are shown.

\section{Discussion}

AMPs are potential candidates for development as new antifungal drugs. Hep 25 is a noncytotoxic human AMP with a broad spectrum of antibacterial activity [15]. In this study, we studied the mechanism by which hep 25 kills C. albicans and found that hep 25 killed C. albicans cells in an energy- and temperature-dependent manner, as determined by the results from the use of chemical inhibitors and reduced temperature conditions (Figure 3A-D). Nevertheless, we also found that nonfermentable glycerol, which forces cells to use mitochondrial oxidative phosphorylation to produce ATP, can enhance the candidacidal activity of hep 25 treated cells. Interestingly, hep 25 also exhibits nonmembrane lytic antimicrobial activity.

Of special interest is the effect of hep 25 on the specific binding of the ATCUN motif to $\mathrm{Cu}$ (II) and $\mathrm{Ni}(\mathrm{II})$ [69]. ATCUN-containing proteins exert various functions. For example, human serum albumin binding to $\mathrm{Cu}(\mathrm{II})$ is associated with metal transportation [70], whereas human protamine HP2 binding with metal is associated with damage to sperm DNA and ROS generation [71]. Moreover, adding an N-terminal ATCUN motif to different AMPs can enhance the activity of these peptides by inducing ROS formation [46]. Moreover, previous studies also indicated that the $\mathrm{Cu}(\mathrm{II})$-ATCUN complex can damage DNA, RNA, proteins and lipids because it induces ROS generation [72-74]. Therefore, ROS are important for AMPs to killing of microbial pathogens [75-78] and are possibly generated through a Fenton-like reaction involving the $\mathrm{Cu}(\mathrm{II})$-ATCUN complex [74,79]. Hence, we first determined the metal dependence of hep 25 on ROS production and killing activity by cotreating cells with the $\mathrm{Cu}$ chelator BCS. Our results indicated that $1 \mathrm{mM}$ BCS not only abrogates ROS production, but also reduces the $C$. albicans killing activity induced by hep 25 (Figures 4 and 5). To further verify the effect of copper chelation on the candidacidal activity of hep 25, $2 \mathrm{mM} \mathrm{BCS}$ was also used [50]. Interestingly, the activity of hep 25 was almost completely inhibited by $2 \mathrm{mM} \mathrm{BCS}$ (Figure S4). Taken together, our findings show that ROS generation is crucial to hep 25 fungicidal activity, and the primary source of ROS is derived from the $\mathrm{Cu}(\mathrm{II})$-ATCUN complex. However, some questions still need to be addressed: For example, how efficiently does BCS compete with hep 25 for copper binding? Does hep 25 acquire copper extracellularly or intracellularly? Does hep 25 impair metal homeostasis? 
Hep 25 does not appear to target the membrane (Figure 2), and it induces ROS generation (Figure 4A,B). Because ROS are associated with yeast apoptosis in many cases [80], it was interested in determining whether hep 25 induces $C$. albicans cell death via apoptosis. In the early phase of apoptosis, the opening of the permeability transition pore causes mitochondrial dysfunction, losses of $\Delta \Psi \mathrm{m}$ and releases of apoptogenic factors into the cytosol [81,82]. Moreover, metacaspases are involved in the apoptotic cascade $[83,84]$. Our results showed that hep25 causes mitochondrial depolarization (Figure 6) and induces metacaspase activation (Figure 7). Finally, Annexin V-FITC and PI double staining and TUNEL assays revealed PS exposure and DNA fragmentation (Figures 8 and 9), which are all important features of apoptosis.

In summary, we demonstrated that hep 25 induces C. albicans apoptosis without disrupting plasma membrane integrity. Moreover, the ATCUN motif of hep 25 is important for the candidacidal activity of the peptide. Therefore, our findings provide important information on how an ATCUN-containing peptide can kill fungal pathogens and demonstrate its potential for future use in antifungal therapy.

Supplementary Materials: The following are available online at http://www.mdpi.com/2076-2607/8/4/585/s1, Figure S1: The activity of hep 25 against various clinical isolates of C. albicans and non-albicans Candida spp. Figure S2: Mitochondrial depolarization detected with DiOC6(3). Figure S3: Mitochondrial depolarization detected by TMRM. Figure S4. The effect of $2 \mathrm{mM} \mathrm{BCS}$ on the candidacidal activity of hep 25. Table S1: Clinical isolates of Candida spp. used in this study. Table S2: Minimal fungicidal concentrations (MFCs) of hep 25 against C. albicans and non-albicans Candida clinical isolates.

Author Contributions: Conceptualization, R.-C.C.; Data curation, R.-C.C.; Formal analysis, R.-C.C.; Funding acquisition, C.-Y.L.; Investigation, R.-C.C.; Methodology, R.-C.C.; Validation, R.-C.C.; Writing-original draft, R.-C.C. and C.-Y.L.; Writing-review \& editing, R.-C.C. and C.-Y.L. All authors have read and agreed to the published version of the manuscript.

Funding: This work was supported by Ministry of Science and Technology (Taiwan) grants MOST108-2311-B-007-005 and MOST105-2311-B-007-007-MY3 (to CYL).

Acknowledgments: We thank Hsiu-Jung Lo for generously providing the clinical strains and the support from the confocal imaging core in National Tsing Hua University (sponsored by MOST 108-2731-M-007-001).

Conflicts of Interest: The authors declare no conflict of interest.

\section{References}

1. Lopez-Medina, E.; Koh, A.Y. The complexities of bacterial-fungal interactions in the mammalian gastrointestinal tract. Microb. Cell 2016, 3, 191-195. [CrossRef] [PubMed]

2. Neville, B.A.; d'Enfert, C.; Bougnoux, M.E. Candida albicans commensalism in the gastrointestinal tract. Fems Yeast Res. 2015, 15. [CrossRef]

3. Enoch, D.A.; Ludlam, H.A.; Brown, N.M. Invasive fungal infections: A review of epidemiology and management options. J. Med. Microbiol. 2006, 55, 809-818. [CrossRef] [PubMed]

4. Kauffman, C.A. Fungal infections. Proc. Am. Thorac. Soc. 2006, 3, 35-40. [CrossRef]

5. Swidergall, M.; Ernst, J.F. Interplay between Candida albicans and the antimicrobial peptide armory. Eukaryot. Cell 2014, 13, 950-957. [CrossRef]

6. Boto, A.; Perez de la Lastra, J.M.; Gonzalez, C.C. The Road from host-defense peptides to a new generation of antimicrobial drugs. Molecules 2018, 23, 311. [CrossRef]

7. Kumar, P.; Kizhakkedathu, J.N.; Straus, S.K. Antimicrobial peptides: Diversity, mechanism of action and strategies to improve the activity and biocompatibility in vivo. Biomolecules 2018, 8, 4. [CrossRef]

8. Hancock, R.E.W.; Sahl, H.-G. Antimicrobial and host-defense peptides as new anti-infective therapeutic strategies. Nat. Biotechnol. 2006, 24, 1551-1557. [CrossRef]

9. Zhang, L.J.; Gallo, R.L. Antimicrobial peptides. Curr. Biol. 2016, 26, R14-R19. [CrossRef]

10. Wu, Q.; Patocka, J.; Kuca, K. Insect antimicrobial peptides, a mini review. Toxins 2018, 10, 461. [CrossRef]

11. Mahlapuu, M.; Hakansson, J.; Ringstad, L.; Bjorn, C. Antimicrobial peptides: An emerging category of therapeutic agents. Front. Cell Infect. Microbiol. 2016, 6, 194. [CrossRef]

12. Wang, G.; Li, X.; Wang, Z. APD3: The antimicrobial peptide database as a tool for research and education. Nucleic Acids Res. 2016, 44, D1087-D1093. [CrossRef] 
13. Wiig, M.E.; Dahlin, L.B.; Friden, J.; Hagberg, L.; Larsen, S.E.; Wiklund, K.; Mahlapuu, M. PXL01 in sodium hyaluronate for improvement of hand recovery after flexor tendon repair surgery: Randomized controlled trial. PLoS ONE 2014, 9, e110735. [CrossRef]

14. Gronberg, A.; Mahlapuu, M.; Stahle, M.; Whately-Smith, C.; Rollman, O. Treatment with LL-37 is safe and effective in enhancing healing of hard-to-heal venous leg ulcers: A randomized, placebo-controlled clinical trial. Wound Repair Regen. 2014, 22, 613-621. [CrossRef]

15. Park, C.H.; Valore, E.V.; Waring, A.J.; Ganz, T. Hepcidin, a urinary antimicrobial peptide synthesized in the liver. J. Biol. Chem. 2001, 276, 7806-7810. [CrossRef] [PubMed]

16. Boumaiza, M.; Abidi, S. Hepcidin cDNA evolution in vertebrates. Vitam. Horm. 2019, 110, 1-16. [CrossRef] [PubMed]

17. Oliveira-Filho, J.P.; Marques, J.A.; Cunha, P.H.J.; Medeiros, G.X.; Riet-Correa, F.; Machado, V.M.V.; Borges, A.S. Sequencing and expression analysis of hepcidin mRNA in donkey (Equus asinus) liver. Pesqui. Vet. Bras. 2012, 32, 1050-1054. [CrossRef]

18. Nemeth, E.; Tuttle, M.S.; Powelson, J.; Vaughn, M.B.; Donovan, A.; Ward, D.M.; Ganz, T.; Kaplan, J. Hepcidin regulates cellular iron efflux by binding to ferroportin and inducing its internalization. Science 2004, 306, 2090-2093. [CrossRef] [PubMed]

19. Michels, K.; Nemeth, E.; Ganz, T.; Mehrad, B. Hepcidin and host defense against infectious diseases. PLoS Pathog. 2015, 11, e1004998. [CrossRef] [PubMed]

20. Abbas, I.M.; Vranic, M.; Hoffmann, H.; El-Khatib, A.H.; Montes-Bayon, M.; Moller, H.M.; Weller, M.G. Investigations of the copper peptide hepcidin-25 by LC-MS/MS and NMR. Int. J. Mol. Sci. 2018, 19, 2271. [CrossRef] [PubMed]

21. Verga Falzacappa, M.V.; Muckenthaler, M.U. Hepcidin: Iron-hormone and anti-microbial peptide. Gene 2005, 364, 37-44. [CrossRef] [PubMed]

22. Maisetta, G.; Petruzzelli, R.; Brancatisano, F.L.; Esin, S.; Vitali, A.; Campa, M.; Batoni, G. Antimicrobial activity of human hepcidin 20 and 25 against clinically relevant bacterial strains: Effect of copper and acidic $\mathrm{pH}$. Peptides 2010, 31, 1995-2002. [CrossRef] [PubMed]

23. Krause, A.; Neitz, S.; Mägert, H.-J.; Schulz, A.; Forssmann, W.-G.; Schulz-Knappe, P.; Adermann, K. LEAP-1, a novel highly disulfide-bonded human peptide, exhibits antimicrobial activity. FEBS Lett. 2000, 480, 147-150. [CrossRef]

24. Jiang, X.F.; Liu, Z.F.; Lin, A.F.; Xiang, L.X.; Shao, J.Z. Coordination of bactericidal and iron regulatory functions of Hepcidin in innate antimicrobial immunity in a zebrafish model. Sci. Rep. 2017, 7, 4265. [CrossRef]

25. Aschi, M.; Bozzi, A.; Di Bartolomeo, R.; Petruzzelli, R. The role of disulfide bonds and N-terminus in the structural properties of hepcidins: Insights from molecular dynamics simulations. Biopolymers 2010, 93, 917-926. [CrossRef]

26. Maisetta, G.; Vitali, A.; Scorciapino, M.A.; Rinaldi, A.C.; Petruzzelli, R.; Brancatisano, F.L.; Esin, S.; Stringaro, A.; Colone, M.; Luzi, C.; et al. pH-dependent disruption of Escherichia coli ATCC 25922 and model membranes by the human antimicrobial peptides hepcidin 20 and 25. FEBS J. 2013, 280, 2842-2854. [CrossRef]

27. Gillum, A.M.; Tsay, E.Y.; Kirsch, D.R. Isolation of the Candida albicans gene for orotidine-5'-phosphate decarboxylase by complementation of S. cerevisiae ura3 and E. coli pyrF mutations. Mol. Gen. Genet. 1984, 198, 179-182. [CrossRef]

28. Lee, J.; Hwang, J.S.; Hwang, I.S.; Cho, J.; Lee, E.; Kim, Y.; Lee, D.G. Coprisin-induced antifungal effects in Candida albicans correlate with apoptotic mechanisms. Free Radic. Biol. Med. 2012, 52, 2302-2311. [CrossRef]

29. Kwolek-Mirek, M.; Zadrag-Tecza, R. Comparison of methods used for assessing the viability and vitality of yeast cells. FEMS Yeast Res. 2014, 14, 1068-1079. [CrossRef]

30. Madeo, F.; Frohlich, E.; Frohlich, K.U. A yeast mutant showing diagnostic markers of early and late apoptosis. J. Cell Biol. 1997, 139, 729-734. [CrossRef]

31. Hao, B.; Cheng, S.; Clancy, C.J.; Nguyen, M.H. Caspofungin kills Candida albicans by causing both cellular apoptosis and necrosis. Antimicrob. Agents Chemoter. 2013, 57, 326-332. [CrossRef] [PubMed]

32. Phillips, A.J.; Sudbery, I.; Ramsdale, M. Apoptosis induced by environmental stresses and amphotericin B in Candida albicans. Proc. Natl. Acad. Sci. USA 2003, 100, 14327-14332. [CrossRef] [PubMed] 
33. Higuchi-Sanabria, R.; Charalel, J.K.; Viana, M.P.; Garcia, E.J.; Sing, C.N.; Koenigsberg, A.; Swayne, T.C.; Vevea, J.D.; Boldogh, I.R.; Rafelski, S.M.; et al. Mitochondrial anchorage and fusion contribute to mitochondrial inheritance and quality control in the budding yeast Saccharomyces cerevisiae. Mol. Biol. Cell 2016, 27, 776-787. [CrossRef] [PubMed]

34. Creed, S.; McKenzie, M. Measurement of mitochondrial membrane potential with the fluorescent dye tetramethylrhodamine methyl ester (TMRM). Method Mol. Biol. 2019, 1928, 69-76. [CrossRef]

35. Shirazi, F.; Kontoyiannis, D.P. Micafungin triggers caspase-dependent apoptosis in Candida albicans and Candida parapsilosis biofilms, including caspofungin non-susceptible isolates. Virulence 2015, 6, 385-394. [CrossRef] [PubMed]

36. Mochon, A.B.; Liu, H. The antimicrobial peptide histatin-5 causes a spatially restricted disruption on the Candida albicans surface, allowing rapid entry of the peptide into the cytoplasm. PLoS Pathog. 2008, 4, e1000190. [CrossRef]

37. Du, H.; Puri, S.; McCall, A.; Norris, H.L.; Russo, T.; Edgerton, M. Human salivary protein histatin 5 has potent bactericidal activity against ESKAPE pathogens. Front. Cell. Infect. Microbiol. 2017, 7, 41. [CrossRef]

38. Puri, S.; Edgerton, M. How does it kill? Understanding the candidacidal mechanism of salivary histatin 5. Eukaryot. Cell 2014, 13, 958-964. [CrossRef]

39. Henriques, S.T.; Quintas, A.; Bagatolli, L.A.; Homblé, F.; Castanho, M.A. Energy-independent translocation of cell-penetrating peptides occurs without formation of pores. A biophysical study with pep-1. Mol. Membr. Biol. 2007, 24, 282-293. [CrossRef]

40. Hayes, B.M.E.; Bleackley, M.R.; Anderson, M.A.; van der Weerden, N.L. The plant defensin NaD1 enters the cytoplasm of Candida albicans via endocytosis. J. Fungi 2018, 4, 20. [CrossRef]

41. Munoz, A.; Marcos, J.F.; Read, N.D. Concentration-dependent mechanisms of cell penetration and killing by the de novo designed antifungal hexapeptide PAF26. Mol. Microbiol. 2012, 85, 89-106. [CrossRef] [PubMed]

42. Jiao, C.Y.; Delaroche, D.; Burlina, F.; Alves, I.D.; Chassaing, G.; Sagan, S. Translocation and endocytosis for cell-penetrating peptide internalization. J. Biol. Chem. 2009, 284, 33957-33965. [CrossRef] [PubMed]

43. El-Andaloussi, S.; Holm, T.; Langel, U. Cell-penetrating peptides: Mechanisms and applications. Curr. Pharm. Des. 2005, 11, 3597-3611. [CrossRef] [PubMed]

44. Cho, J.; Lee, D.G. Oxidative stress by antimicrobial peptide pleurocidin triggers apoptosis in Candida albicans. Biochimie 2011, 93, 1873-1879. [CrossRef]

45. Kim, S.; Lee, D.G. Role of calcium in reactive oxygen species-induced apoptosis in Candida albicans: An antifungal mechanism of antimicrobial peptide, PMAP-23. Free Radic. Res. 2019, 53, 8-17. [CrossRef]

46. Libardo, M.D.; Cervantes, J.L.; Salazar, J.C.; Angeles-Boza, A.M. Improved bioactivity of antimicrobial peptides by addition of amino-terminal copper and nickel (ATCUN) binding motifs. ChemMedChem 2014, 9 , 1892-1901. [CrossRef]

47. Libardo, M.D.; Nagella, S.; Lugo, A.; Pierce, S.; Angeles-Boza, A.M. Copper-binding tripeptide motif increases potency of the antimicrobial peptide anoplin via reactive oxygen species generation. Biochem. Biophys. Res. Commun. 2015, 456, 446-451. [CrossRef]

48. Santoro, A.; Walke, G.; Vileno, B.; Kulkarni, P.P.; Raibaut, L.; Faller, P. Low catalytic activity of the $\mathrm{Cu}$ (ii)-binding motif ( $\mathrm{Xxx}$-Zzz-His; ATCUN) in reactive oxygen species production and inhibition by the $\mathrm{Cu}(\mathrm{i})$-chelator BCS. Chem. Commun. 2018, 54, 11945-11948. [CrossRef]

49. Libardo, M.D.; Gorbatyuk, V.Y.; Angeles-Boza, A.M. Central Role of the copper-binding motif in the complex mechanism of action of ixosin: Enhancing oxidative damage and promoting synergy with ixosin B. ACS Infect. Dis. 2016, 2, 71-81. [CrossRef]

50. Conklin, S.E.; Bridgman, E.C.; Su, Q.; Riggs-Gelasco, P.; Haas, K.L.; Franz, K.J. Specific histidine residues confer histatin peptides with copper-dependent activity against Candida albicans. Biochemistry 2017, 56, 4244-4255. [CrossRef]

51. Pan, Y.; Schroeder, E.A.; Ocampo, A.; Barrientos, A.; Shadel, G.S. Regulation of yeast chronological life span by TORC1 via adaptive mitochondrial ROS signaling. Cell Metab. 2011, 13, 668-678. [CrossRef] [PubMed]

52. Mokudai, T.; Kanno, T.; Niwano, Y. Postantifungal-like effect of sublethal treatment of Candida albicans with acid-electrolyzed water. Arch. Oral Biol. 2015, 60, 479-487. [CrossRef] [PubMed]

53. Sendzik, M.; Pushie, M.J.; Stefaniak, E.; Haas, K.L. Structure and affinity of Cu(I) bound to human serum albumin. Inorg. Chem. 2017, 56, 15057-15065. [CrossRef] [PubMed] 
54. Esmieu, C.; Guettas, D.; Conte-Daban, A.; Sabater, L.; Faller, P.; Hureau, C. Copper-targeting approaches in alzheimer's disease: How to improve the fallouts obtained from in vitro studies. Inorg. Chem. 2019, 58, 13509-13527. [CrossRef] [PubMed]

55. Guilloreau, L.; Combalbert, S.; Sournia-Saquet, A.; Mazarguil, H.; Faller, P. Redox chemistry of copper-amyloid-beta: The generation of hydroxyl radical in the presence of ascorbate is linked to redox-potentials and aggregation state. Chembiochem 2007, 8, 1317-1325. [CrossRef] [PubMed]

56. Perrone, G.G.; Tan, S.X.; Dawes, I.W. Reactive oxygen species and yeast apoptosis. Biochim. Biophys. Acta 2008, 1783, 1354-1368. [CrossRef]

57. Farrugia, G.; Balzan, R. Oxidative stress and programmed cell death in yeast. Front. Oncol. $2012,2,64$. [CrossRef]

58. Carmona-Gutierrez, D.; Eisenberg, T.; Buttner, S.; Meisinger, C.; Kroemer, G.; Madeo, F. Apoptosis in yeast: Triggers, pathways, subroutines. Cell Death Differ. 2010, 17, 763-773. [CrossRef]

59. Perry, S.W.; Norman, J.P.; Barbieri, J.; Brown, E.B.; Gelbard, H.A. Mitochondrial membrane potential probes and the proton gradient: A practical usage guide. BioTechniques 2011, 50, 98-115. [CrossRef]

60. Krysko, D.V.; Roels, F.; Leybaert, L.; D'Herde, K. Mitochondrial transmembrane potential changes support the concept of mitochondrial heterogeneity during apoptosis. J. Histochem. Cytochem. 2001, 49, 1277-1284. [CrossRef]

61. Eisenberg, T.; Buttner, S.; Kroemer, G.; Madeo, F. The mitochondrial pathway in yeast apoptosis. Apoptosis Int. J. Program. Cell Death 2007, 12, 1011-1023. [CrossRef] [PubMed]

62. Bell, R.A.V.; Megeney, L.A. Evolution of caspase-mediated cell death and differentiation: Twins separated at birth. Cell Death Differ. 2017, 24, 1359. [CrossRef] [PubMed]

63. Lee, W.; Lee, D.G. Reactive oxygen species modulate itraconazole-induced apoptosis via mitochondrial disruption in Candida albicans. Free Radic. Res. 2018, 52, 39-50. [CrossRef] [PubMed]

64. Seong, M.; Lee, D.G. Reactive oxygen species-independent apoptotic pathway by gold nanoparticles in Candida albicans. Microbiol. Res. 2018, 207, 33-40. [CrossRef] [PubMed]

65. Jia, C.; Zhang, J.; Yu, L.; Wang, C.; Yang, Y.; Rong, X.; Xu, K.; Chu, M. Antifungal Activity of Coumarin Against Candida albicans Is Related to Apoptosis. Front. Cell. Infect. Microbiol. 2019, 8. [CrossRef] [PubMed]

66. Herker, E.; Jungwirth, H.; Lehmann, K.A.; Maldener, C.; Fröhlich, K.U.; Wissing, S.; Büttner, S.; Fehr, M.; Sigrist, S.; Madeo, F. Chronological aging leads to apoptosis in yeast. J. Cell Biol. 2004, 164, 501-507. [CrossRef] [PubMed]

67. Singh, B.R.; Gupta, V.K.; Deeba, F.; Bajpai, R.; Pandey, V.; Naqvi, A.H.; Upreti, D.K.; Gathergood, N.; Jiang, Y.; El Enshasy, H.A.; et al. Non-toxic and ultra-small biosilver nanoclusters trigger apoptotic cell death in fluconazole-resistant Candida albicans via Ras signaling. Biomolecules 2019, 9, 47. [CrossRef]

68. Hwang, J.H.; Choi, H.; Kim, A.R.; Yun, J.W.; Yu, R.; Woo, E.R.; Lee, D.G. Hibicuslide C-induced cell death in Candida albicans involves apoptosis mechanism. J. Appl. Microbiol. 2014, 117, 1400-1411. [CrossRef]

69. Tselepis, C.; Ford, S.J.; McKie, A.T.; Vogel, W.; Zoller, H.; Simpson, R.J.; Diaz Castro, J.; Iqbal, T.H.; Ward, D.G. Characterization of the transition-metal-binding properties of hepcidin. Biochem. J. 2010, 427, 289-296. [CrossRef]

70. Rózga, M.; Sokołowska, M.; Protas, A.M.; Bal, W. Human serum albumin coordinates Cu(II) at its N-terminal binding site with 1 pM affinity. J. Biol. Inorg. Chem. 2007, 12, 913-918. [CrossRef]

71. Bal, W.; Jeżowska-Bojczuk, M.; Kasprzak, K.S. Binding of nickel(II) and copper(II) to the N-terminal sequence of human protamine HP2. Chem. Res. Toxicol. 1997, 10, 906-914. [CrossRef] [PubMed]

72. Singh, R.K.; Sharma, N.K.; Prasad, R.; Singh, U.P. DNA cleavage study using copper (II)-GlyAibHis: A tripeptide complex based on ATCUN peptide motifs. Protein Pept. Lett. 2008, 15, 13-19. [CrossRef] [PubMed]

73. Agbale, C.M.; Cardoso, M.H.; Galyuon, I.K.; Franco, O.L. Designing metallodrugs with nuclease and protease activity. Met. Integr. Biomet. Sci. 2016, 8, 1159-1169. [CrossRef] [PubMed]

74. Gonzalez, P.; Bossak, K.; Stefaniak, E.; Hureau, C.; Raibaut, L.; Bal, W.; Faller, P. N-terminal Cu-binding motifs (Xxx-Zzz-His, Xxx-His) and their derivatives: Chemistry, biology and medicinal applications. Chem. A Eur. J. 2018, 24, 8029-8041. [CrossRef] [PubMed]

75. Cho, J.; Lee, D.G. The antimicrobial peptide arenicin-1 promotes generation of reactive oxygen species and induction of apoptosis. Biochim. Biophys. Acta 2011, 1810, 1246-1251. [CrossRef] [PubMed] 
76. Wang, K.; Dang, W.; Xie, J.; Zhu, R.; Sun, M.; Jia, F.; Zhao, Y.; An, X.; Qiu, S.; Li, X.; et al. Antimicrobial peptide protonectin disturbs the membrane integrity and induces ROS production in yeast cells. Biochim. Biophys. Acta 2015, 1848, 2365-2373. [CrossRef]

77. Hwang, B.; Hwang, J.S.; Lee, J.; Kim, J.K.; Kim, S.R.; Kim, Y.; Lee, D.G. Induction of yeast apoptosis by an antimicrobial peptide, Papiliocin. Biochem. Biophys. Res. Commun. 2011, 408, 89-93. [CrossRef]

78. Lee, J.; Lee, D.G. Melittin triggers apoptosis in Candida albicans through the reactive oxygen species-mediated mitochondria/caspase-dependent pathway. FEMS Microbiol. Lett. 2014, 355, 36-42. [CrossRef]

79. Libardo, M.D.; Paul, T.J.; Prabhakar, R.; Angeles-Boza, A.M. Hybrid peptide ATCUN-sh-Buforin: Influence of the ATCUN charge and stereochemistry on antimicrobial activity. Biochimie 2015, 113, 143-155. [CrossRef]

80. Madeo, F.; Fröhlich, E.; Ligr, M.; Grey, M.; Sigrist, S.J.; Wolf, D.H.; Fröhlich, K.U. Oxygen stress: A regulator of apoptosis in yeast. J. Cell Biol. 1999, 145, 757-767. [CrossRef]

81. Li, R.; Zhang, R.; Yang, Y.; Wang, X.; Yi, Y.; Fan, P.; Liu, Z.; Chen, C.; Chang, J. CGA-N12, a peptide derived from chromogranin A, promotes apoptosis of Candida tropicalis by attenuating mitochondrial functions. Biochem. J. 2018, 475, 1385-1396. [CrossRef] [PubMed]

82. Canton, M.; Caffieri, S.; Dall'Acqua, F.; Di Lisa, F. PUVA-induced apoptosis involves mitochondrial dysfunction caused by the opening of the permeability transition pore. FEBS Lett. 2002, 522, 168-172. [CrossRef]

83. Tsiatsiani, L.; Van Breusegem, F.; Gallois, P.; Zavialov, A.; Lam, E.; Bozhkov, P.V. Metacaspases. Cell Death Differ. 2011, 18, 1279-1288. [CrossRef] [PubMed]

84. Hwang, I.S.; Lee, J.; Hwang, J.H.; Kim, K.J.; Lee, D.G. Silver nanoparticles induce apoptotic cell death in Candida albicans through the increase of hydroxyl radicals. FEBS J. 2012, 279, 1327-1338. [CrossRef]

(C) 2020 by the authors. Licensee MDPI, Basel, Switzerland. This article is an open access article distributed under the terms and conditions of the Creative Commons Attribution (CC BY) license (http://creativecommons.org/licenses/by/4.0/). 